\title{
Entry Qualifications and Entrepreneurial Competency Acquisition among Tertiary Institution Students in Kenya
}

\author{
Rose Moindi $^{*}$ Benard Nyatuka Sorobea Bogonko \\ Department of Educational Foundations, Kisii University, P. O Box 408-40200, Kisii, Kenya
}

\begin{abstract}
This study sought to determine the influence of tertiary institution students' entry qualifications to entrepreneurship education on acquisition of the requisite competencies in Kisii County, Kenya. The study was guided by Ajzen's (1991) theory of planned behaviour and adopted the cross sectional design. Proportionate stratified sampling technique was employed to select a sample of 124,142 and 146 second year diploma students from Kisii University (KSU), Kisii National Polytechnic (KNP) and Keroka Technical Training Institute (KTI), respectively in the 2019/2020 academic year to participate in the study. The heads of the business and ICT departments (HODs) and the alumni officers were purposely involved as well. Data from students was obtained by use of questionnaires while the HODs and alumni officers were interviewed. Data was analysed both quantitatively and qualitatively. The study revealed that the entry qualification of students was pegged on performance in the Kenya Certificate of Secondary Education (KCSE). It was also established that those students with lower qualifications in KCSE, but had progressively pursued entrepreneurship education tended to acquire competencies more effectively compared to those who had direct entry into the course. The study recommends the teaching of entrepreneurship education in secondary schools as a means of improving not only the entry qualifications of students, but also enhancing acquisition of the relevant competencies.
\end{abstract}

Keywords: Entry qualification, entrepreneurship education, tertiary institution, competencies, course, unit.

DOI: $10.7176 / \mathrm{JEP} / 11-26-10$

Publication date:September $30^{\text {th }} 2020$

\subsection{Introduction}

Both the developed and developing countries are facing challenges of unemployment and low economic growth (Ozaralli, \& Rivernburgh, 2016; Eijdenberg, Thompson, Verduijn \& Esser, 2019). According to the United Nations (2018), entrepreneurship is viewed as a solution to the fast changing economic demands across the globe, including unemployment and a path to sustainable economic development. It is on this premise that the United Nations Educational, Scientific and Cultural Organisation has recommended the teaching of entrepreneurship education in the tertiary institutions (UNESCO, 2016; UN, 2018). This is because studies have showed that entrepreneurship education has the potential to equip students with competencies that will enable them to seek employment or set up their own enterprises successfully (Chimucheka, 2014; Pangesa, Fuston \& Kumar, 2014; Bacigalupo, Punie \& Brande, 2016; Ho, Uy, Kang \& Chan, 2018; McCallum, Weicht, McMullan \& Price, 2018; Tola \& Chimucheka, 2018). It is these competencies, according to the Organisation for Economic Cooperation and Development (McCallum, Weicht, McMullan, \& Price, 2018), that will enable students to spot opportunities, enhance self-awareness, spur creativity, work with others and take initiatives among other competencies which are required to develop an entrepreneurial mind-set.

China, which is a rapidly developing country, faces high rates of unemployment among scholars, whereby out of the $4.5 \%$ of the unemployed persons, $8.5 \%$ of them are scholars (Kaijun \& Sholihah, 2015). To obviate this situation, entrepreneurship education was introduced as a pilot study by the Ministry of Education in nine public higher educational institutions in 2002 and since then, many colleges and universities have adopted this innovation in education (Zhou \& Xu, 2012). According to a study conducted by Kaijun and Sholihah (2015), the introduction of entrepreneurship education in China has had a positive effect on student's intentions to be entrepreneurs and consequently led to increased economic growth.

Kenya had introduced entrepreneurship education in 1988 compared to China where it was introduced in 2002 (Republic of Kenya, 1988; Zhou \& Xu, 2012). However, the impact of this course to the Chinese economy is evident compared to the Kenyan one (Republic of Kenya, 2012a; Kaijun \& Sholihah, 2015). This is attributed to the methods of teaching entrepreneurship education in China which enables students to link theory to real situations in the market (Li, Zhang \& Matlay, 2008; Lee, Chang \& Lim, 2005; Zhou \& Xu, 2012; Kaijun \& Sholihah, 2015; Ozaralli \& Rivernburgh, 2016). However, limited information is available as to the appropriate entry qualifications of students to study entrepreneurship education in the tertiary institutions.

A study of selected African countries, including Zambia, Ghana, Kenya, Benin and Togo showed that the highest share of secondary school students who had enrolled in the formal tertiary institutions had increased by over 100\% in 2007 (Kingombe, 2011). The move by African countries to increase enrolment in tertiary institutions is backed by the Sustainable Development Goal (SDG) Number 4 that focuses on the need to enable students who have completed secondary schools to have access to these institutions (UN, 2018). However, the effect of 
entrepreneurship education to national economy has not been widely felt. This is evident through the high instances of unemployment revealed by different studies in Africa (Lokoko, Rankhumise \& Ras, 2012; Aja-Okorie \& Adali, 2013; Adejei, Pinkrah \& Denanyoh, 2014). Therefore, there is urgent need to improve on the quality of entrepreneurship education. This is because entrepreneurship education would impact on the country's GDP (UN, 2018). It is on this backdrop that this study sought to determine the influence of entry qualification to entrepreneurship education on acquiring the expected competencies among students.

In Kenya, the entry qualification to pursue a diploma course has been set at a minimum grade of C- (C minus) in the KCSE examination (Republic of Kenya, 2019). However, students with lower qualifications in the examination are allowed to join diploma courses after completion of a similar certificate course (Republic of Kenya, 2018; KUCCPS, 2018, Kisii University, 2008). This implies that in addition to the performance in KCSE, there were students in this study who had an earlier exposure to the course. This is why this study sought to determine the effect of entry qualifications of students to entrepreneurship education on acquisition of the anticipated competencies.

\subsection{Admission requirements to diploma courses}

Diploma programmes in Kenya are offered to students in the tertiary institutions, including universities, national polytechnics and technical training institutes (Republic of Kenya, 2012c; 2013a). The criteria to join these institutions is developed by the Kenya National Qualification Framework (KNQF) (Republic of Kenya, 2018; 2019). According to the KNQF, persons eligible for diploma courses should have one of the following qualifications:

1. Obtained a C- in the KCSE examination

2. Obtained Division II in the Kenya Certificate Education (KCE) examination

3. At least one principal pass at the Kenya Advanced Certificate of Education (KACE) examination

4. Completion of KNQF Level 5 or

5. Awarded Certificate of Experiential Learning issued by the KNQF (Republic of Kenya, 2018).

The cut-off grade for the diploma programmes was lowered from $\mathrm{C}$ plain to $\mathrm{C}$ - in order to encourage more Form Four graduates to apply for the same (Oduor, 2018). In addition to these qualifications, students can progress from a certificate course to a similar diploma level course on completion of the certificate course (Republic of Kenya, 1999; 2018). This implies that persons who scored D+ and below in KCSE can progress to diploma level on completion of a similar certificate course through career progression (Oduor, 2018; Republic of Kenya, 2018; 2013). Therefore, students who joined diploma courses through career progression qualification had been exposed to entrepreneurship education for a longer period compared to those who joined for diploma programmes directly from secondary schools.

In addition to the mean grade of $\mathrm{C}$ - attained in the $\mathrm{KCSE}$, students are required to have scored a minimum of $\mathrm{C}$ plain in Mathematics, English and Kiswahili in order to be placed by the KUCCPS in the respective public TVET institutions (KUCCPS, 2018). At Kisii University, students needed to have scored a minimum of C- in Mathematics as an entry requirement for a diploma programme (Kisii University, 2008). This shows a disparity in the entry requirement for the same course. With this information, this study sought to compare the influence of entry qualification of students in the three institutions to entrepreneurship education in enabling them to acquire the requisite competencies.

Universities, national polytechnics and technical training institutes in Kenya offer similar diploma courses to their students (Republic of Kenya 2012a; Wanzala, 2016; Akala \& Changilw, 2018). In addition to this, the Report of the Commission of Inquiry into the Education system in Kenya recommended progression of graduates from diploma to degree courses in universities as a means of offering continued education for the affected students (Republic of Kenya, 1999). However, it has been observed by Oduor (2018) that students prefer to join universities for diploma courses in comparison to the other institutions. This was attributed to the smooth transition to do degree courses for diploma graduates in the university compared to the TVET diploma graduates. Thus, despite the difference in the choice of tertiary institutions by diploma students, those who had done diploma in the university were selectively preferred to proceed to the universities for degree courses compared to their counterparts in the TVET institutions.

In a bid to encourage more students to join public TVET institutions, the government included diploma courses in the national placement procedure (KUCCPS, 2018). Government placement for diploma courses also saw the school fees being subsidised. This move is also backed with provision of loans to the diploma students to fund their education by the Higher Education Loans Board (HELB) (Ndurya, 2010; Republic of Kenya, 2018). Despite these incentives given to students in the public TVET institutions (where students in KNP and KTI are set to benefit), students would still prefer to join diploma courses offered in the universities (Odour, 2018). It is on this backdrop that this study sought to compare the entry qualifications to entrepreneurship education in these institutions in as well as gaining of requisite competencies. 


\subsection{Theoretical framework}

This study was guided by the theory of planned behaviour (Ajzen, 1991) as well as the EntreComp model (Bacigalupo, Kampylis, Punie \& Brande, 2016).

\subsubsection{Theory of planned behaviour}

According to the theory, attitudes towards the behaviour, perceived behaviour control and subjective norms inform a person's intentions to perform or not perform a particular behaviour (Figure 1).

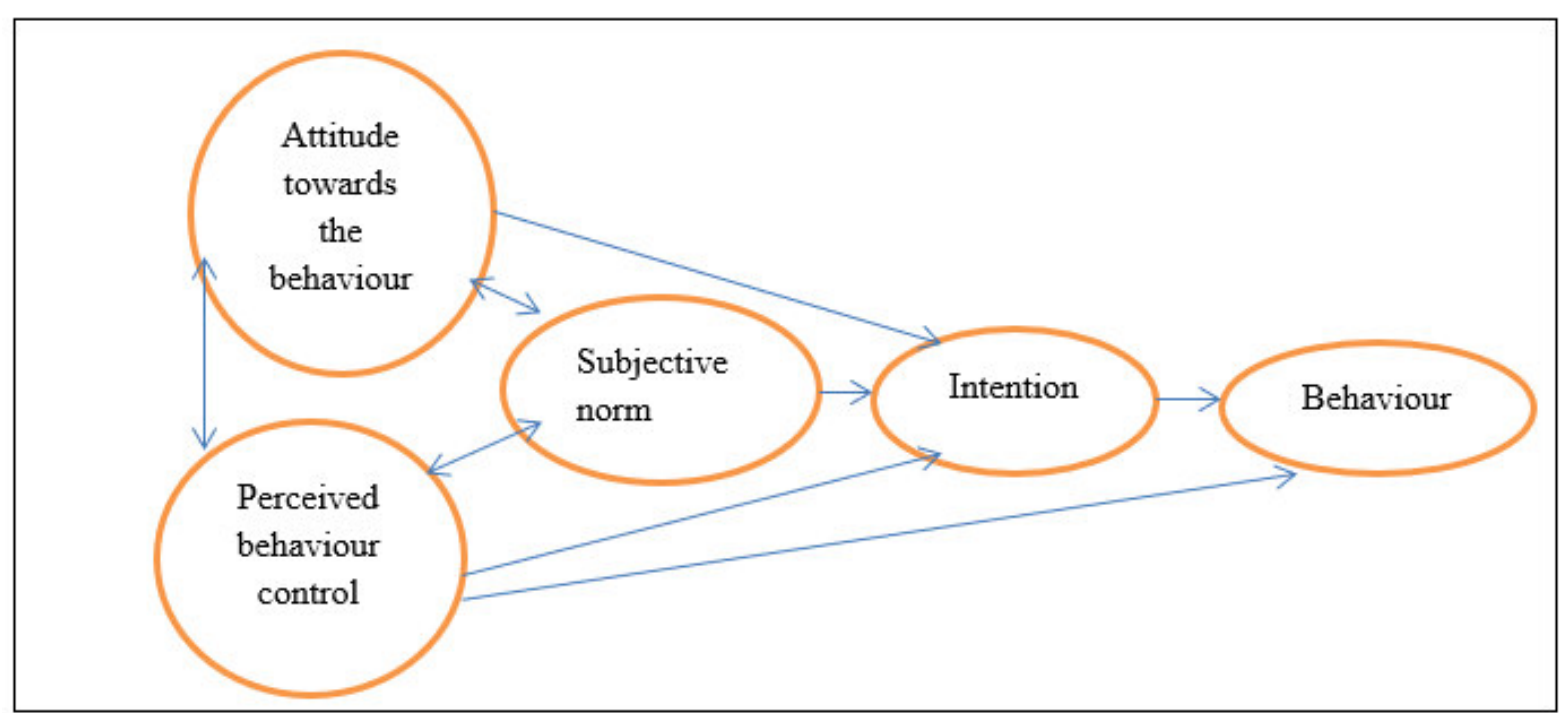

Figure 1.1 Theory of planned behaviour (Source: Adapted from Ajzen, 1991)

Perceived behaviour control encompasses the resources and opportunities available to a person which dictate the likelihood of behaviour achievement and the ease or difficulty of performing the behaviour (Ajzen, 1991). Attitude towards the behaviour encompasses a person's believe and attitude towards a particular behaviour. This will depend on how positively or negatively an individual evaluates performance of a particular behaviour (Malebana, 2016). On the other hand, subjective norm is the perceived social pressure to perform or not to perform certain behaviour (Ajzen, 1991). This will depend on a person's social referents. The student's cognition as well as their environment which to a great extent is determined by the curriculum and type of institution will influence the subjective norm of the student and ultimately their intention. Intentions are motivational factors that influence behaviour and a person's behaviour is influenced by the confidence in their ability to perform it (Ajzen, 1991).

Self-efficacy is when a person believes that their outcomes are determined by their own behaviour (internal locus control) (Bandura, 1991). Therefore, people's behaviours are strongly influenced by their confidence in their ability to perform (Ajzen, 1991). In this study, the student's entry qualification would enable them to acquire the requisite competencies to form intentions of becoming an entrepreneur which is the ultimate behaviour. Therefore, the entry qualification to entrepreneurship education is expected to enable the students to acquire competencies to become entrepreneurs.

\subsubsection{The EntreComp Model}

There has been an increasing move to codify entrepreneurial competencies so as to design and deliver appropriate educational responses (McCallum, Weicht, McMullan, \& Price, 2018; Mokhtar, 2017). Accordingly, entrepreneurial competencies have been clustered into competency areas to enable researchers to distinguish the role and relative importance of competencies in influencing outcomes from any entrepreneurial activity. As a result, models have been developed to describe different competencies. In this study, the comprehensiveness of entrepreneurship education was determined by use of the EntreComp model to assess the learning outcomes of each entrepreneurial competency acquired by a student undertaking entrepreneurship education (Bacigalupo, Kampylis, Punie \& Brande, 2016).

The EntreComp framework has grouped 15 entrepreneurial competencies into three competence areas; ideas and opportunities, resources, and into-action (Figure 1.2) (Bacigalupo, Kampylis, Punie \& Brande, 2016). This makes the framework ideal in the development of curricula and learning activities to foster acquisition of entrepreneurial competencies while teaching entrepreneurship education to students (Bacigalupo, Kampylis, Punie \& Brande, 2016). The EntreComp framework also presents a set of expected learning outcomes in each competency (McCallum, Weicht, McMullan, \& Price, 2018). Hence, because of the comprehensiveness of the EntreComp model in assessing the expected learning outcomes in each competency, it was ideal for this study. 


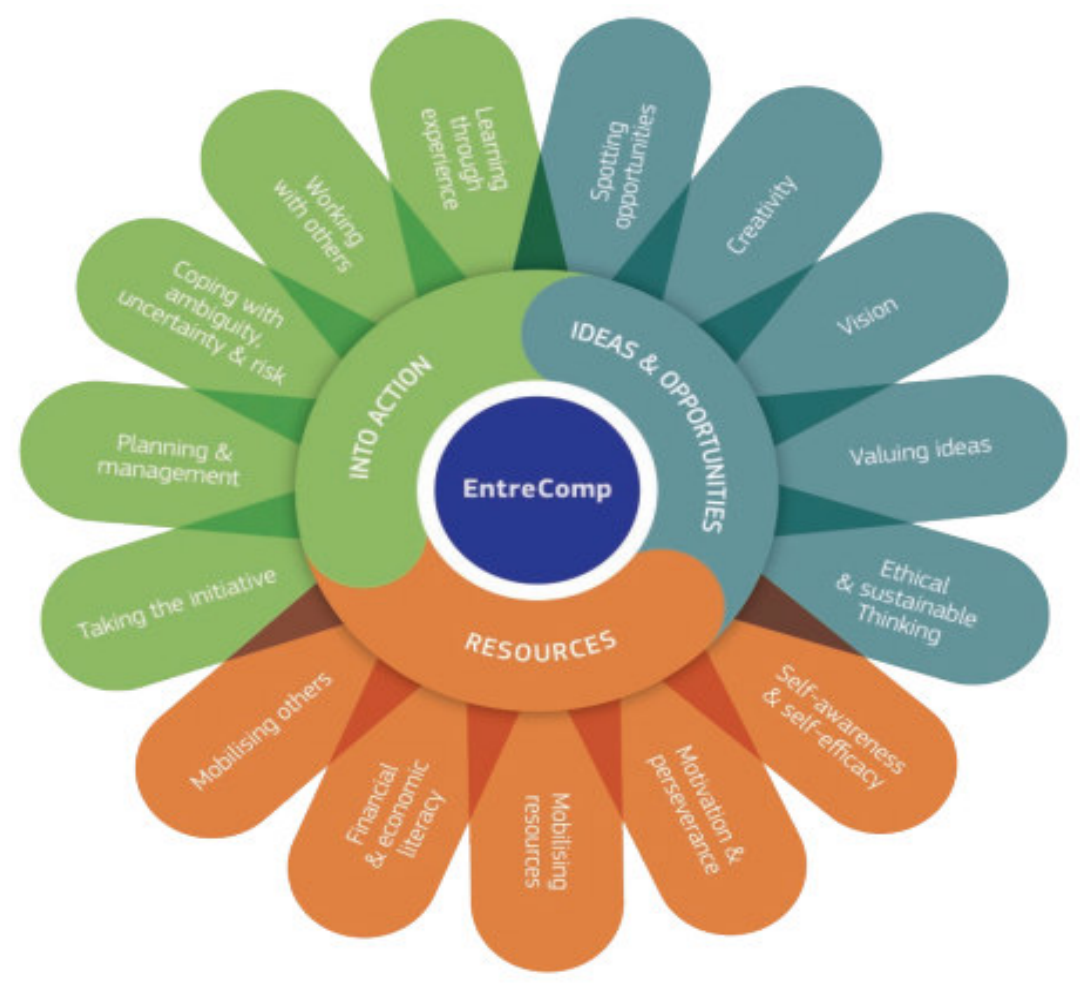

Figure 1.2 The EntreComp wheel

(Source: McCallum, Weicht, McMullan \& Price, 2018

In this study, the dependent variable was requisite competencies while the dependent variable was entrepreneurship education entry qualification. The competencies were categorised into three competency areas which are ideas and opportunities, resources and into-actions (Bacigalupo, Punie \& Brande, 2016).

\subsection{Statement of the Problem}

Universities as well as TVET institutions were established for purposes of supplying skilled human resource for both the public and the private sectors in Kenya. Particularly, diploma programmes have gained much popularity in these tertiary institutions. However, courses in business and information technology (ICT) have seen high enrolment. It is expected therefore, that the curriculum of these courses be carefully designed to provide specific competencies to students that are relevant to the local Kenyan economy and more specifically, one that will enable graduates in these courses to fit into the economic activities of their local communities. One such course that has been emphasised and integrated into the curriculum is entrepreneurship education. It is expected to enable students acquire and develop skills for entrepreneurship. However, while the KUCCPS and Commission for University Education have set up the entry qualification for diploma programmes as attainment of a mean grade of C- in the KCSE or its equivalent, limited information is available as to the influence of the entry qualification of students pursuing these diploma programmes in the acquisition of entrepreneurial competencies. It is on this backdrop that the study sought to determine the influence of the student's entry qualification to selected diploma courses in KSU, KNP an KTI on acquisition of the requisite entrepreneurial competencies.

\subsection{Methodology}

This study adopted a cross sectional research design as a means of obtaining a holistic understanding of the phenomenon being studied from particular groups of respondents at a particular "point in time" (Kesmodel, 2018).

\subsection{Target Population}

This study targeted 180 students in KSU, 220 students in KNP and 230 students in KTI who were in their second year of study in the 2019/20 academic year (Keroka Technical Training Institute, 2019; Kisii National Polytechnic, 2019; Kisii University, 2019). This is because, these students had already been taught entrepreneurship education thus would be relatively knowledgeable about the relevant entrepreneurial competencies. These students were pursuing diploma courses in Information Technology (IT)/Information Communication Technology (ICT), human/personnel resource management, supply-chain/store management and business 
management/administration. One of the units done by students pursuing these diploma courses is entrepreneurship education. Therefore, this study sought to determine the influence of the students' entry qualification in pursuing entrepreneurship education on acquisition of entrepreneurial competencies.

\subsection{Sampling Technique and Sample Size}

Proportionate stratified sampling technique was applied to arrive at the sample size in this study. This is a probability sampling technique where the entire population is divided into sub-groups or strata then the researcher randomly selects the final subjects proportionately from the different strata (Deshpande \& Grime, 2019). The sample size for students in each tertiary institution was determined using Glenn (2012) sample size determination formula which is presented below.

$$
\mathrm{n}=\frac{\mathrm{N}}{1+\mathrm{N}(\mathrm{e}) 2}
$$

Where;

$\mathrm{n}$ - Sample size $=$ to be determined

$\mathrm{N}$ - Target population $=$ students in each institution

e- Level of precision $=0.05$

Using this formula, the sample size for students in the three institutions was calculated and presented as shown in Table 2.2.

Table 2.1 Sample size in the three institutions

\begin{tabular}{|l|l|l|l|}
\hline Institution & KSU & KNP & KTI \\
\hline Target population N & 180 & 220 & 230 \\
\hline $\begin{array}{c}\text { Glen's formula } \\
\quad=\frac{\mathbf{N}}{\mathbf{1 + N}(\mathbf{e}) \mathbf{2}}\end{array}$ & $=\frac{180}{1+180(0.05) 2}$ & $=\frac{220}{1+220(0.05) 2}$ & $=\frac{230}{1+230(0.05) 2}$ \\
\hline Sample size & 124 & 142 & 146 \\
\hline
\end{tabular}

Using the sample size of 124 students in KSU, 142 students in KNP and 146 students in KTI, proportionate distribution of students in each course was calculated and presented in Table 2.2. Thus Table 2.2 shows the students sample size in each diploma course in each tertiary institution.

Table 2.2 Proportionate Distribution in each Course in each Institution

\begin{tabular}{|c|c|c|c|c|}
\hline Institution & Diploma course (strata) & $\begin{array}{c}\text { Population } \\
\mathrm{N}\end{array}$ & $\begin{array}{l}\text { Proportionate } \\
\text { ratio \% }\end{array}$ & $\begin{array}{l}\text { Sample } \\
\text { size (n) }\end{array}$ \\
\hline \multirow[t]{5}{*}{ KTI } & 1.Personnel/human-resource management & 45 & $20(45 / 230)$ & 29 \\
\hline & 2.Supply-chain/stores and supplies management & 68 & $30(68 / 230)$ & 44 \\
\hline & 3.Businesss management/ Administration & 70 & $30(70 / 230)$ & 44 \\
\hline & 4. ICT/IT & 47 & $20(47 / 230)$ & 29 \\
\hline & Total in KTI & 230 & & 146 \\
\hline \multirow[t]{5}{*}{ KNP } & 1.Personnel/human-resource management & 67 & $30(67 / 220)$ & 43 \\
\hline & 2.Supply-chain/stores and supplies management & 58 & $26(58 / 220)$ & 37 \\
\hline & 3.Businesss management/ Administration & 39 & $18(39 / 220)$ & 26 \\
\hline & 4. ICT/IT & 56 & $25(56 / 220)$ & 36 \\
\hline & Total in KNP & 220 & & 142 \\
\hline \multirow[t]{5}{*}{$\mathrm{KSU}$} & 1.Personnel/human-resource management & 35 & $19(35 / 180)$ & 24 \\
\hline & 2.Supply-chain/stores and supplies management & 28 & $16(28 / 180)$ & 20 \\
\hline & 3.Businesss management/ Administration & 65 & $36(65 / 180)$ & 45 \\
\hline & 4. ICT/IT & 52 & $29(52 / 180)$ & 36 \\
\hline & Total in KSU & 180 & & 124 \\
\hline
\end{tabular}

According to Creswell (2014), participants should be purposely selected in order to answer the research questions in the study. In this study, each institution has HoDs in charge of business department and IT department as well as the alumni officers. The HoDs are directly in charge of the students pursuing diploma courses in IT/ICT, human/personnel resource management, supply-chain/store management and business management/administration. On the other hand the alumni officer is in charge of the alumni students of the institution. These HoDs and alumni officers were purposely selected since they had attributes that were required in this study.

\subsection{Research Instruments}

Both student questionnaires and interview schedules were used to collect data. The student's questionnaires contained both five point Likert scale items as well as open ended items. The closed ended questions were appropriate in collecting data from a large group of respondents (Jamli \& Salim, 2019). The open ended questions 
were used to confirm the previous responses in the closed ended questions (Zohrabi, 2013). This process of obtaining data by use of different means of data collection would allow for the triangulation of the research results (Simon, 2011; Zohrabi, 2013). A pilot study was done to enhance the reliability and validity of the tools. Particularly, validity was sought by use of different procedures of data collection from different respondents, a phenomenon described by Zohrabi (2013) as triangulation. Thus in additions to the student's questionnaires where data was collected by use of Likert scale and open ended questions, there were interview schedules conducted for the HODs and alumni officers. Thus triangulation of the different questionnaires from different respondents helped in validating the findings (Simon, 2011; Zohrabi, 2013).

\subsection{Data Analysis}

Once the questionnaires had been filled, the raw data was then classified into homogeneous groups so that the data with common characteristics was placed in the same group (Kothari, 2014). The raw data were edited before coding. Then the coded data were entered into the Excel spread sheet which was then exported to the Statistical Package for Social Sciences (SPSS) version 2.2 which allowed for the analysis of the data (Lutabingwa \& Auriacombe, 2007). Quantitative and qualitative methods were used to conduct data analyses. Analysis of quantitative data involved the use of both descriptive and inferential statistics.

\subsection{Results}

\subsection{Return rate of Questionnaires}

In this study a total of 124, 142 and 146 student's questionnaires were dispatched to KSU, KNP and KTI. However, $116(93.5 \%), 124(87.3 \%)$ and $144(98.6 \%)$ in KSU, KNP and KTI questionnaires were filled and returned, respectively. Consequently, above $87.3 \%$ of the dispatched questionnaires were filled and returned. According to Fincham (2008), a questionnaires return rate of above $60 \%$ is appropriate for analysis.

\subsection{Findings of the study}

\subsubsection{Entry qualifications}

The KUCCPS has set the entry qualification (EQ) for diploma course at a minimum of C- in the KCSE examination. From the study as shown in Figure 3.1 beow, $80 \%$ of the students in the three institutions had joined diploma programmes on completion of their secondary education. On the other hand, $20 \%$ had joined progressively upon completion of the respective certificate course. This implies that tertiary institutions have followed the government policy of admitting students with a mean grade of $\mathrm{C}$ - and above in the KCSE and those with a lower mean grade had completed a certificate in the same examination.

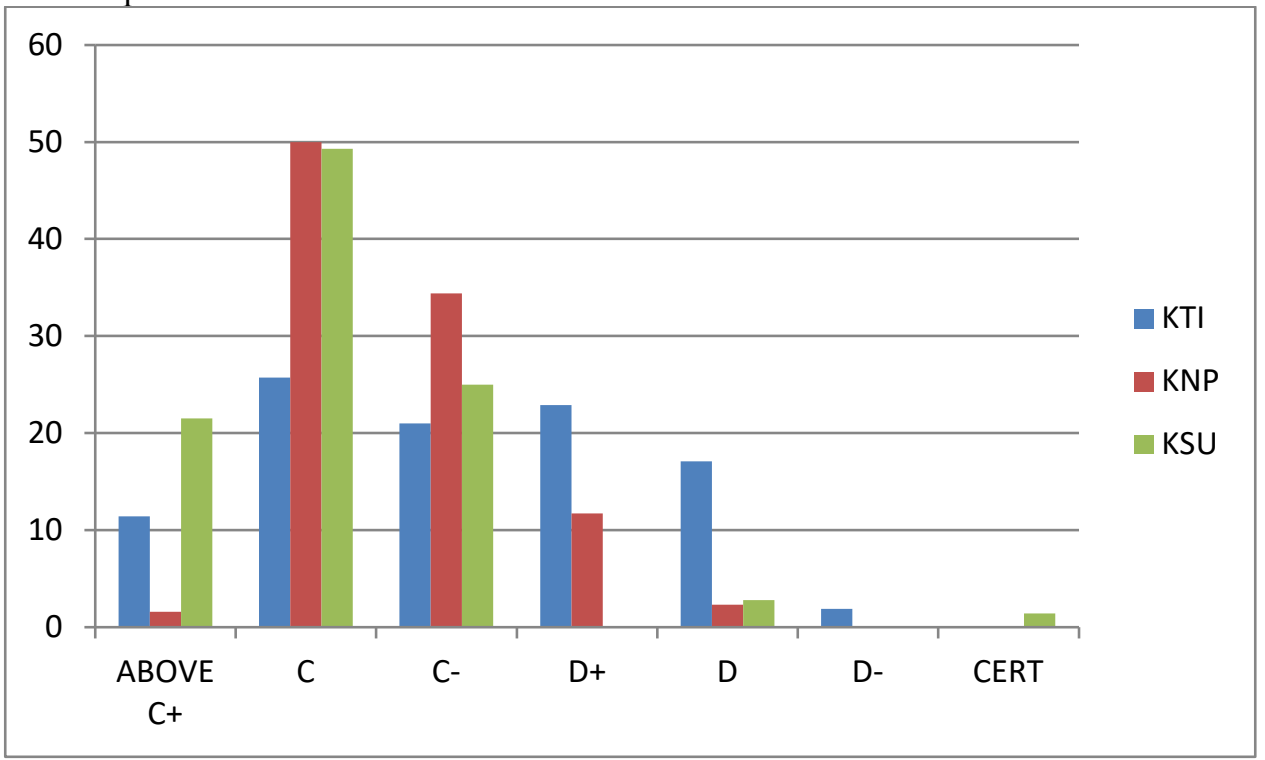

Figure 3.1 Entry qualifications per institution

When the entry qualification of students in the three institutions is compared, KSU generally had admitted more students with higher qualifications in KCSE whereby $95.8 \%$ had scored a mean grade of C- and above. This was followed by the students in KNP where $86 \%$ had scored a mean grade of C- and above in KCSE compared to KTI where $58.1 \%$ had scored a mean grade of C- and above. This implied that KSU and KNP enrolled more students with higher qualifications compared to KTI.

On the other hand more students in KTI $(42 \%)$ had scored a mean grade of D+ and below in KCSE compared to those enrolled in KNP (14\%) and KSU (4.2\%). Students who had scored a mean grade of below C- in KCSE 
had to have completed a similar course at the certificate level before being enrolled for diploma level (Republic of Kenya, 2018). Thus these students had the opportunity of studying entrepreneurship education at the certificate level compared to those who scored a $\mathrm{C}$ - and above since they were admitted directly from their secondary schools where entrepreneurship education was not taught.

\subsubsection{Level at which entrepreneurship education was taught}

When the HODs were asked about the level at which students were taught entrepreneurship education, the HODs in KNP and KTI said it was during their Module One (first year). On the other hand, the HODs in KSU observed that entrepreneurship education was taught in the first semester of the second year.

These levels were deemed appropriate by all the HODs in the three institutions. However, when the level at which entrepreneurship education was taught was compared in the three institutions, the students in the university were taught the unit much later, that is, during the second year, compared to those in KNP and KTI who were taught during first year. This implied that students in KSU were taught the unit much later when other units which might have contributed to the understanding of entrepreneurship education had been taught and understood compared to those in KNP and KTI.

\subsubsection{Student's Interest in the Entrepreneurship Education Unit}

The HODs were asked to state if the student's interest were put into considerations before teaching entrepreneurship education. The HOD in the business department in KNP and the ICT counterpart in KSU observed that career guidance was offered to students as they chose the various courses. However, all the HODs observed that students' interest was not taken into consideration in the choice of the entrepreneurship education as it was a core unit. This implied that when choosing units and especially entrepreneurship education the student's interest was not taken into consideration since this was a core unit that was taught to all diploma students in the business and ICT departments of the three institutions.

However, the alumni officers from the three institutions observed that when students graduated, they would set up businesses which were not basically in line with what they studied. For instance, the alumni officer in KSU observed that most of the students had set up cyber café business, a venture they had not studied. Therefore, the unit entrepreneurship education enabled these students to run their businesses effectively despite the fact that they did not set up enterprises in their line of studies.

\subsubsection{Effectiveness in acquisition of competencies}

The HODs were asked to comment on the effectiveness of acquiring the requisite competencies among the students. This item was included to determine whether the HODs were able to distinguish these students in the process of enabling them acquire competencies. It was observed that students who had done certificate in the similar course were frequently chosen by the HODs in ICT in KNP and KTI. This result is similar to the study by Obwoge, Mosol, Emarah, Keraro and Kangethe (2017) which showed that despite the fact that medical students in Kenya are required to have performed well in the cluster subjects in KCSE, performance in the preclinical course depends on the performance in the course and not the previous performance in KCSE. This implied that performance in entrepreneurship education at diploma level depended upon previous qualification compared to the performance in KCSE. That is, students who were being taught entrepreneurship education for the second time would acquire competencies effectively compared to the students who were taught this unit for the first time as was observed in the students who enrolled directly from secondary schools.

\subsubsection{Entry Qualifications contribution to Competency Areas}

The Likert scale items in the student's questionnaires were grouped into three competency areas (See appendix I). To determine whether the student's entry qualification to study entrepreneurship education contributed to the acquisition of these three competency areas; ideas and opportunities, resources and into-action, the questionnaires from the three institutions were analysed and presented in Figure 3.2. 


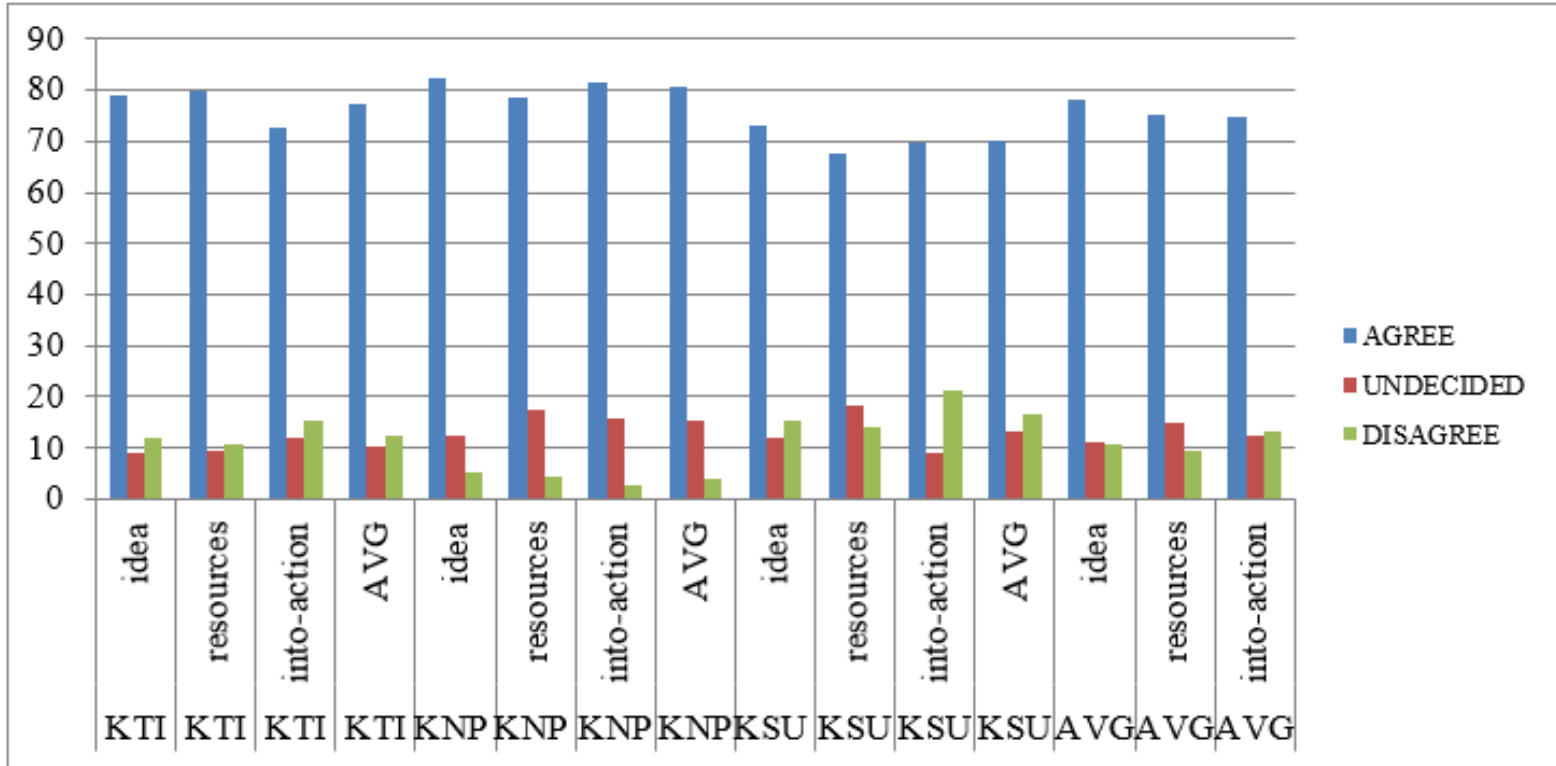

Figure 3.2 Entry Qualifications and Acquisition of Competencies

This study shows that students in the three institutions agreed that their entry qualification influenced their understanding of ideas and opportunities competencies. When the three institutions were compared, majority of students in KNP (82.4\%) reported that their entry qualification did influence their acquisition of ideas and opportunities competencies compared to those in KTI (79\%) and KSU (73\%). On the other hand, $15.2 \%$ of students in KSU disagreed that their entry qualification influenced their acquisition of ideas and opportunities competencies.

When the students were asked whether their entry qualification influenced their understanding of resources competencies, majority of students $79.9 \%$ in KTI and $78.4 \%$ in KNP agreed compared to $67.4 \%$ in KSU. On the other hand, majority $(81.4 \%)$ of students in KNP agreed that their entry qualification influenced their understanding of into-action competencies, compared to KTI (72.6\%) and KSU (69.9\%). Similarly, more students $(21.3 \%)$ in KSU disagreed that their entry qualification influenced their understanding of into-action competencies compared to those in KNP (2.6\%) and KTI (15.3\%).

\subsubsection{Influence of Entry Qualification on Acquisition of Competencies}

To ascertain this, a regression analysis was conducted using the following simple regression model:

$\mathrm{C}_{\mathrm{EQ}}=\beta_{1} \mathrm{EQ}_{1}+\beta_{2} \mathrm{EQ}_{2}+\beta_{3} \mathrm{EQ}_{3}$.

Where $C_{\mathrm{EQ}}$ is the student's entry qualification

$\mathrm{EQ}_{1}$ denotes the ideas and opportunities component of entrepreneurial competencies

$\mathrm{EQ}_{2}$ denotes resources component of entrepreneurial competencies

$\mathrm{EQ}_{3}$ denotes the into-action component of entrepreneurial competencies.

Table 3.1 shows the summary of the output of the ultimate model.

Table 3.1 Entry qualification and acquisition of requisite competencies

\begin{tabular}{lclll}
\hline & Coefficients & Standard Error & t Stat & P-value \\
\hline Intercept & 0 & 0 & 0 & 0 \\
$\mathrm{EQ}_{1}$ & 0.399 & 0.062 & 6.394 & 0.000 \\
$\mathrm{EQ}_{2}$ & 0.233 & 0.061 & 3.824 & 0.000 \\
$\mathrm{EQ}_{3}$ & 0.127 & 0.060 & 2.107 & 0.036 \\
\hline
\end{tabular}

The competencies associated to entry qualification are estimated using the equation below;

$\mathrm{C}_{\mathrm{EQ}}=0.399 \mathrm{EQ}_{1}+0.233 \mathrm{EQ}_{2}+0.127 \mathrm{EQ}_{3} \quad\left(\mathrm{R}^{2}=80.6 \%, \mathrm{R}=0.90\right)$

The $\mathrm{R}$ value (multiple correlation coefficients) measures the quality of the prediction of the dependent variable in this case in the entry qualification. In the model, the $\mathrm{R}$ value of 0.90 indicated that there was a strong positive correlation between the entry qualification and acquisition of requisite competencies $\left(\mathrm{EQ}_{1}, \mathrm{EQ}_{2}\right.$ and $\left.\mathrm{EQ}_{3}\right)$. This implies that entry qualification to entrepreneurship education has a very strong positive correlation to acquisition of requisite competencies. The $\mathrm{R}^{2}$ value was $80.6 \%$; this indicated that there was $80.6 \%$ chance that the entry qualification influenced acquisition of competencies $\left(\mathrm{EQ}_{1}, \mathrm{EQ}_{2}\right.$ and $\left.\mathrm{EQ}_{3}\right)$. This means that the entry qualification to a great extent influenced how students acquired the competencies. Thus, $19.4 \%$ can be explained by other factors not considered in this study.

Results from Table 3.1 indicate that all aspects of entrepreneurial competences associated to ideas and opportunities, resources and into-action competency areas have a positive influence on entry qualification. Therefore, a change in one aspect of entry qualification associated to ideas and opportunities by one unit while the 
other factors are held constant, the acquisition of competencies will change positively by 0.399 units. Like-wise, a change in one aspect of entry qualification associated to resources by one unit while other factors are held constant, the acquisition of competencies will change positively by 0.233 units and finally, a change in one aspect associated with into-action by one unit while the other factors are held constant, the acquisition of competencies will positively increase by 0.127 . It can therefore be observed that the entry qualification to entrepreneurship education to a great extent influenced the understanding of how to develop ideas and opportunities (0.399) competencies more followed by resources $(0.233)$ and finally into-action $(0.127)$.

The P-values of 0.000 for $\mathrm{EQ}_{1}, 0.000$ for $\mathrm{EQ}_{2}$ and 0.036 for $\mathrm{EQ}_{3}$ are all less than $0.05(\mathrm{P}<0.05)$. This implies that the entry qualification to entrepreneurial education was significant in influencing how students acquired competencies on ideas and opportunities, resources and into-action competencies $\left(\mathrm{EQ}_{1}, \mathrm{EQ}_{2}\right.$ and $\left.\mathrm{EQ}_{3}\right)$. To determine how well this regression equation predicted the requisite competencies $\left(\mathrm{EQ}_{1}, \mathrm{EQ}_{2}\right.$ and $\left.\mathrm{EQ}_{3}\right)$, the analysis of variance (ANOVA) was conducted and the resulting model in Table 3.2 was obtained.

Table 3.2 Entry qualification influence on acquisition of requisite competencies

\begin{tabular}{lrrrrr}
\hline & df & SS & MS & F & F crit \\
\hline Regression & 3 & 1198.773 & 399.590 & 524.050 & 0.000 \\
Residual & 378 & 288.227 & 0.7625 & & \\
\cline { 1 - 3 } Total & 381 & 1487 & & & \\
\hline
\end{tabular}

Source: Current study

The F-ratio value of 524.050 with 3 and 378 degrees of freedom has a probability of occurring by chance alone of less than 0.000 . Therefore, there is a significant difference between the three groups $[\mathrm{F}(3,378)=524.05>$ 0.05]. Thus it can be concluded that there is a significant difference between the ideas and opportunities, resources and into-action (EQ1 EQ2 and EQ3) in their explaining effect to acquisition of requisite competencies. Therefore, despite students doing entrepreneurial education having a similar entry qualification (mean grade of C-and above in KCSE or its equivalent); there is a statistically significant difference in how entry qualification to entrepreneurship education influenced how these students acquired the three requisite competency areas (ideas and opportunities, resources and into-action).

To estimate how the students varied between the institutions, an ANOVA analysis for the responses obtained were represented in Table 3.3

Table 3.3 Influence of entry qualification to institutions on competence acquisition

\begin{tabular}{lrrrrrr}
\hline Source of Variation & SS & df & MS & F & P-value & F crit \\
\hline Between Groups & 7.26 & 2 & 3.63 & 4.38 & 0.01 & 3.02 \\
Within Groups & 313.67 & 378 & 0.83 & & & \\
\cline { 1 - 3 } Total & 320.93 & 380 & & & &
\end{tabular}

Source: Current Study

The $\mathrm{F}$ ratio is greater than the $\mathrm{F}$ critical ( $\mathrm{F}$ ratio $>\mathrm{F}$ critical), $[\mathrm{F}=(2,378) 4.38>3.02]$. This implied that there was a significant difference in how the entry qualification in the three institutions influenced how students acquired the requisite competencies. The $\mathrm{P}$ value of 0.01 is less that 0.05 ( $\mathrm{P}$ value $<0.05)$ (Table 3.3). This suggests that there is a significant difference in how the entry qualification of the students to the different institutions influenced how they acquired the requisite competencies. Thus it can be concluded that despite the fact the diploma students had almost similar entry qualification, there was a significantly difference in how this influenced how they acquired the requisite competencies.

\subsection{Discussion}

Students in the three tertiary institutions were presumed to have had a similar entry qualification by the KNQF. However, this study established that there was a significant difference in the entry qualification of students doing similar courses in the three tertiary institutions (F Value $>$ F critical, $4.38>3.02$ ). This influenced how students in these institutions acquired competencies. The differences in the entry qualifications of the students were established in respect to the performance in the KCSE and earlier exposure to entrepreneurship education. This study established that more students in KTI (42\%) and KNP (14\%) compared to those in KSU (4.2\%) had scored a mean grade of $\mathrm{D}+$ and below in KCSE. Therefore, while the students who had scored $\mathrm{D}+$ and below were not admitted for diploma courses, they were required to have studied for a similar certificate course which lasted two years (Republic of Kenya, 2019). This means that these students had an earlier exposure to entrepreneurship education compared to those students who had joined the tertiary institutions directly from secondary schools. This inferred that repeated exposure to entrepreneurship education as observed in the students who had scored D+ and below in KCSE at certificate levels improved their entry qualification to entrepreneurship education at diploma level. This contributed to the effectiveness of acquisition of competencies by students in KTI.

Up to $77 \%$ of students in KTI compared to $70 \%$ of students in KSU agreed that their entry qualification influenced their effectiveness of acquisition of entrepreneurial competencies. Thus acquisition of entrepreneurial 
competencies improves in the case of students who had an earlier exposure and thus were being taught a similar unit at a higher level compared to those who were taught the entrepreneurship education for the first time at diploma level. This observation is backed by the multiple correlation coefficients $(\mathrm{R})$ of 0.90 which indicated that there was a strong positive relationship between the influence of the student's entry qualification and their acquisition of the requisite competencies. This is because, when the student's entry qualifications were increased through repeated exposure to the same unit, then they would acquire entrepreneurial competencies more.

Figure 4.1 shows the overall effectiveness of entrepreneurship education on acquisition of competencies as per the findings of this study..

\begin{tabular}{|c|c|c|}
\hline \multicolumn{2}{|c|}{ Independent variable } \\
\hline $\begin{array}{l}\text { Entrepreneurship education } \\
\left(\mathrm{R}^{2}=80.6 \%, \mathrm{R}=0.90\right)\end{array}$ \\
\hline
\end{tabular}

Figure 4.1 Influence of entry qualification on Acquisition of Competencies

\section{Source: Developed from the Current study}

Figure 4.1 Influence of entry qualification on Acquisition of Competencies

Source: Developed from the Current study

The figure indicates that the entry qualification has a strong positive correlation on the acquisition of entrepreneurial competencies $(\mathrm{R}=0.90)$. This implies that an increase in the entry qualification of the student would positively influence acquisition of entrepreneurial competencies. The entry qualification also influenced how students acquired entrepreneurial competencies compared to the other factors $(19.4 \%)$ not studied in this study. While the $\mathrm{P}$ values of the three competency areas were below 0.05 , the analysis of the three competency areas indicated that entry qualification influenced acquisition of ideas and opportunities competences (0.399) followed by resources competencies $(0.233)$ and finally the into-action competencies $(0.127)$. This implies entry qualification to entrepreneurship education influenced acquisition of ideas and opportunities more compared to resources and finally into-action.

\subsection{Conclusion}

This study sought to assess the influence of entry qualification to entrepreneurship education on acquisition of entrepreneurial competencies. The study revealed that students who join tertiary institutions for diploma courses had an almost similar entry qualification of $\mathrm{C}$ - and above. However, more of the students who had enrolled for diploma courses in the university had scored C- and above in KCSE compared to those who had enrolled in the technical training institution. It is important to note that students who had scored a mean grade of $\mathrm{D}+$ and below in $\mathrm{KCSE}$ had done a certificate course hence enabled them to acquire entrepreneurial competencies more effectively compared to those who had joined diploma courses from secondary schools but had scored C- and above in KCSE. This implied that earlier exposure to the unit increased the student's entry qualification. Thus this study established that there was a significant difference in the entry qualification of students in the three tertiary institutions. There is need therefore, to increase the entry qualification to entrepreneurship education by introducing this unit in the secondary schools.

\subsection{Acknowledgments}

We gratefully acknowledge and thank all the respondents, staff of Kisii University and all those who helped us conduct this research successfully.

\section{Reference}

Adejei, K., Pinkrah, B. S. \& Denanyoh, R. (2014). Barrier to Entrepreneurship among business students in Sunyani 
Polytechnic of Ghana. International Journal of Innovative Research and Development, 3(4), 30-36. Retrieved from www.ijird.com $>$ issue $>$ view

Aja-Okoire, U \& Adali, O. (2013). Achieving Youth Empowerment through Repositioning entrepreneurship education in Nigerian Universities: Problems and Prospects. European Scientific Journal, 9(28). Retrieved from https://eujournal.org>esj>article

Ajzen, I. (1991). The Theory of Planned Behaviour. Organizational Behaviour and Human Decision Processes, 50(2), 179-211. Retrieved from https://dx.doi.org/10.1016/0749-5978(91)90020-T

Akala, W. J and Changilwa, P. (2018). Status of Technical and Vocational Education and Training TVET) in Postsecondary Education in Kenya. Journal of Popular Education in Africa. 2(7), 15-25. http://www.jopea.org/index.php/current-issue

Asiamah, N., Mensah, H. K. \& Oteng- Abayie, E. F. (2017). General Target, Accessible Population: Demystifying the concepts for Effective Sampling. The Qualitative Report, 22(6), 1607-1622. Retrieved from, $\mathrm{jttp} / /$ nusuworks.nova,edu/tqr/vol22

Bacigalupo, M. Kampylis, P. Punie, Y. \& Brande, L.V. (2016).EntreComp: The Entrepreneurship Competencies Framework. Luxembourg: Publication office of the European Union. doi:10.2791/593884

Bandura, A. (1991). Social Cognitive Theory of self-Regulation. Organizational Behaviour and Human Decision Processes, 50(2), 248-287. Retrieved from http://dx.doi.org/10.1016/0749.5978(91)90022-L

Chimucheka, T. (2014).Entrepreneurship Education in South Africa. Mediterranean journal of social sciences, 5(2), 150-158. doi:10.5901/mjss.20145n20403

Deshpande, B \& Grime, A. (2019). Sampling Technics. Advances and Applications in Mathematical Sciences, 18(10), 1058-1062. Doi.1021149323aams_vol_1810_august_2019_a7_p1055-1062

Eijdenberg, E. L., Thompson, N. A. Verduijn, K. \& Esser, C. (2018). Entrepreneurial activities in a developing Country: An Institutional Theory Perspective. International Journal of Entrepreneurial Behavior and Research, 25(1). Doi: 10.1108/IJEBR-12-2016-048

Fincham, J. E. (2008). Response Rates and Responsiveness for Surveys, Standards, and the Journal. American Journal of Pharmaceutical Education, 72(2), 43. Doi:10.5688/aj720243.

Glenn, I. (2012). Determining Sample Size. IFAS Extension: University of Florida. Available at https://www.tarleton.edu/academicassesment/document/samplesize.pdf Retrieved on 10 December, 2018

Grecu, V. \& Denes, C. (2017). Benefits of Entrepreneurship education and training for engineering students. MATEC web of Conferences, 121:12007. Doi.10.1051/matecconf/201712112007.

Ho, M., Uy, M. A., Kang, B. N. Y. \& Chan, K. (2018). Impact of Entrepreneurship Training and Alertness among Adolescent Youth. Frontiers in Education, Educational Psychology, https://doi.org/10.3389/feduc.2018.00013

Jamli, N. F. A., \& Salim, S. S. S. (2019). Development of an Instrument to Evaluate Emotional Intelligence and Leadership Style of Headmasters across Primary Schools in Malaysia. International Journal of Academic Research in Business and Social Sciences, 9(7), 988-993. DOI: 10.6007/IJARBSS/v9-i7/6197

Kaijun, Y.\& Sholihah, P.I. (2015). A Comparative Study of Indonesian and China Education systems Concerning the Dominant incentives to Entrepreneurial spirit (Desire for a new venturing) of business school students. Journal of Innovation and Entrepreneurship: A Systems View across Time and Space,4(1). doi.org/10.1186/513731.014-00146-0

Kenya Universities and Colleges Central Placement Service (KUCCPS). (2018).Clarification: Government Sponsorship for TVET Students. Nairobi $8^{\text {th }}$ June 2018. Retrieved from https://www.kuccps.net/?=content/clarification...tvet-students

Keroka Technical Training Institute. (2018). July Admissions, Kisi

Kesmodel, U. S. (2018). Cross-sectional studies - what are they good for? Acta Obstet Gynecol Scand, 97, 388393; Doi: 10.1111/aogs.13331

Kingombe, C. K. M. (2011). Mapping the New Infrastructure Financing Landscape, London: Overseas Development Institute.

Kisii National Polytechnic [Brochure]. (2015). Kisii National Polytechnic. Kisii, Kenya: Kisii National Polytechnic.

Kisii National Polytechnic. (2019) July Admissions, Kisii.

Kothari, C. R. (2014). Research Methodology: Methods and Techniques. New Delhi, New Age International (P) Limited Publishers. Pages 18- 40

Kuratko, D. F. (2005). The Emergence of Entrepreneurship Education: Development, Trends, and Challenges. Entrepreneurship Theory and Practice, 29(5), 577-597. Retrieved from https://doi.org/10.1111/j.15406520.200099.x

Lee, S. Chang, D. \& Lim, S. (2005). Impact of Entrepreneureship Euducation: A comparative study of the USA and Korea. The International Entrepreneureshipmand Management Journal, 1(1), 27-43. Doi.10.1007/511365-005-6674-2 
Li, J., Zhang, Y. \& Matlay, H. (2008).Entrepreneurship education in China.Education and training, 45 (8/9), 495-505. doi:101108/00400910310508883

Lokoko, A., Rankhumise, E. M., \& Ras, P. (2012). The effectiveness of Entrepreneurship education: What matters most? African Journal of Business Management, 6(51), 12023-12033

Lutabingwa, J. \& Auriacombe, C. J. (2007). Data Analysis in Qualitative Research. Journal of Public Administration, 42(6), 528-548. ISSN: 0036-0767

Malebana, M. J. (2016). The influencing role of social capital in the formation of entrepreneurial intention. Southern African Business Review, 20, 51-70.

McCallum, E., Weicht R., McMullan L., \& Price A. (2018). EntreComp into Action: get inspired, make it happen (M. Bacigalupo \& W. O'Keeffe Eds.), EUR 29105 EN, Publications Office of the European Union, Luxembourg. ISBN 978-92-79-79360-8, doi:10.2760/574864, JRC109128.

Mokhtar, A. (2017). A study of Competencies that Influence EntrepreneurPerformance in Retail Business Ventures in Malaysia, DBA thesis, Southern Cross University, Lismore, NSW. Retrieved from https://epubs.scu.edu.au.thesis.

Mukhwana, E,. Oure, S., Kiptoo, S., Kande, A., Njue, R., Too, J. \& Some, D. K. (2016). State of University Education in Kenya. Commission for University Education: Discussion Paper 04. Nairobi, Kenya.

Ndurya, M. (2010, June $\left.13^{\text {th }}\right)$. Diploma Students to get HELB Loans, Sunday Nation $13^{\text {th }}$ June 2010 . Retrieved from https://www.nation.co.ke>news

Nyerere, J. (2018). Youth Unemployment in Kenya: Incorporating Entrepreneurial and Transferable Skills in Education. F. Kapfudzaruwa, M. Nagao, \& E. Mutisya (Ed) in Youth Entrepreneurship and Africa's Sustainable Industrialisation. Spears Media Press ISBN: 978-1-942876-33-5

Obwoge, R. O., Mosol, J. P., Mohamed, E.A. Keraro, F. N. \& Kangethe, S. (2017). Medical Students' KCSE Grade and their Relationship to academic performance: A case of Egerton and Moi Universities, Kenya. Science Journal in Education, 5(2), 34-44. Doi:10116481j.sjedu.2017050211.

Oduor, A. (2018, August $14^{\text {th }}$ ). Reprieve for 100,000 KCSE students as Diploma entry grade lowered, Saturday Standard Newspaper $14^{\text {th }}$ August 2018

Ozaralli, N. \& Rivernburgh, N.K. (2016). Entrepreneurial Intention: Antecedents to Entrepreneurial Behaviour in the USA and Turkey. Journal of Global Entrepreneurship Research, 2016, 6(3). Retrieved from https://doi.org/10.1186/s40497-016-0047-x

Pangesa, G. Fuston, N. P. \& Kumar, S. (2014). Factors that affect entrepreneurial growth in Bekasi Region, Indonesia. International Journal of Scientific and Research Publications, 4(1), 1-8. www.ijsrp.org>ijsrp$\mathrm{p} 2543$.

Republic of Kenya. (1988). The Presidential Session Paper. Kamunge Report. Nairobi: Government printer.

Republic of Kenya. (2012a). Session Paper No. 14 of 2012 on Reforming Education and Training Sectors in Kenya. Nairobi: Government Printer.

Republic of Kenya. (2012b).Technical and Vocational Education and Training (TVET) Policy Nairobi: Government Printer.

Republic of Kenya. (2013a). The Technical and Vocational Education and Training Act, 2013.Nairobi, Government Printer, 833-876.

Republic of Kenya. (2018). Kenya National Qualification Framework number22 of 2014. Nairobi: Government Printer.

Republic of Kenya. (2019). Ministry of Education sessional paper No.1 of 2019 on policy framework for reforming education and training for sustainable development in Kenya. Nairobi: Government Printer.

Sanchez, J. C., (2013). The impact of an Entrepreneurship Education programme on entrepreneurial Competence and Intention. Journal of Small Business Management, 51(3). doi.org/10.111/jsbm.12025.

Simon, M. K. (2011). Dissertation and Scholarly Research: Recipe for success. Seattle, W. A. (Ed). Dissertation success, LLC. http://dissertation recipes.com

Strategies for Technical and Vocational Education and Training

Tola, Z. \& Chimucheka, T. (2018). The Importance of Entrepreneurial Competencies on the Performance of Women Entrepreneurs in South Africa. Journal of Applied Business Research, 34(2), 223-236. doi:10.19030/jabr.v34i2.10122

United Nations Educational Scientific and Cultural Organisation, UNESCO. (2016). Strategies for Technical and Vocational Education and Training (TVET)(2016-2021). France: UNESCO

Wanzala, O. (2016, February, 19). Matiangi upgrades 8 Technical Institutes to National Polytechnics, The Daily Nation, February $19^{\text {th }}, 2016$

Zhou, M. \& Xu, H. (2012). A Review of Entrepreneurship Education for college students in China. Administrative Sciences, 2(1), 82-98. Doi: 10.3390/admsci2010082

Zohrabi, M. (2013). Mixed Method Research: Instrument Validity, Reliability and Reporting Findings, Theory and Practice in Language Studies, 3(2), 254-262. doi:10.4304/tpls.3.2.254-262 


\section{APPENDIX I}

\section{STUDENT'S QUESTIONNAIRE}

1. What was your previous qualification before enrolling in this institution?

a) Kenya Certificate of Secondary Education (KCSE)

b) Kenya Certificate of Education (KCE)

c) Kenya Advanced Certificate of Education (KACE)

d) Certificate of experiential learning

e) Any other, please specify

2. What was your score in the qualification above?

Indicate the extent to which you agree with the following statements with regard to your ability to learn entrepreneurship education based on your entry qualification using a scale of: 1 strongly agree, 2 agree, 3 Undecided, 4 disagree, 5 strongly disagree

\begin{tabular}{|c|l|l|l|l|l|l|}
\hline S/No. & $\begin{array}{l}\text { Competency } \\
\text { area }\end{array}$ & $\begin{array}{l}\text { In your own assessment, did your entry qualification to study } \\
\text { entrepreneurship education your } \\
\text { understanding on how to: }\end{array}$ & $\mathbf{1}$ & $\mathbf{2}$ & $\mathbf{4}$ & $\mathbf{5}$ \\
\hline 1. & $\begin{array}{l}\text { Idea and } \\
\text { opportunity }\end{array}$ & $\begin{array}{l}\text { Develop business ideas and act independently } \\
\text { opportunity }\end{array}$ & $\begin{array}{l}\text { Have confidence to try out new innovative approaches in a } \\
\text { business idea }\end{array}$ & & & \\
\hline 2. & $\begin{array}{l}\text { Idea and } \\
\text { Idea Recognise the potential of an entrepreneurship }\end{array}$ & & & \\
\hline 4. & $\begin{array}{l}\text { Idea and } \\
\text { opportunity }\end{array}$ & Asses the consequences of an entrepreneurial idea & & \\
\hline 5. & resources & Get most out of the limited resources & & & \\
\hline 6. & $\begin{array}{l}\text { resources } \\
\text { Estimate the cost } \text { of turning a business idea into a value creating } \\
\text { activity }\end{array}$ & & & \\
\hline 7. & Into-action & Seek support to achieve your desired outcomes & & & \\
\hline 8. & Into-action & Create teams/ network and learn from others & & \\
\hline
\end{tabular}

